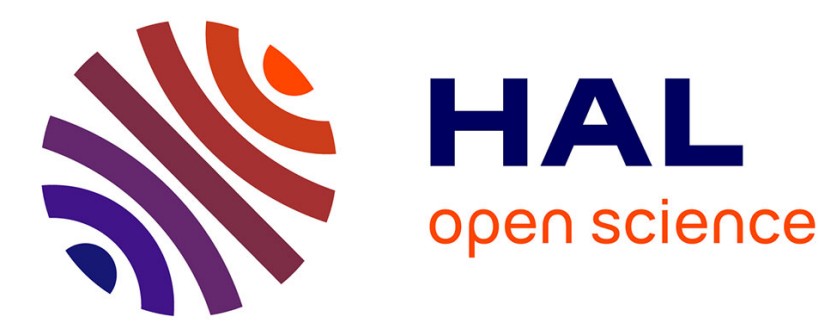

\title{
Shaping the landscape: agricultural policies and local biodiversity schemes
}

\author{
N. Turpin, P. Dupraz, C. Thenail, A. Joannon, J. Baudry, S. Herviou, P. \\ Verburg
}

\section{- To cite this version:}

N. Turpin, P. Dupraz, C. Thenail, A. Joannon, J. Baudry, et al.. Shaping the landscape: agricultural policies and local biodiversity schemes. Land Use Policy, 2009, 26 (2), p. 273 - p. 283. 10.1016/j.landusepol.2008.03.004 . hal-00453894

\section{HAL Id: hal-00453894 https://hal.science/hal-00453894}

Submitted on 5 Feb 2010

HAL is a multi-disciplinary open access archive for the deposit and dissemination of scientific research documents, whether they are published or not. The documents may come from teaching and research institutions in France or abroad, or from public or private research centers.
L'archive ouverte pluridisciplinaire HAL, est destinée au dépôt et à la diffusion de documents scientifiques de niveau recherche, publiés ou non, émanant des établissements d'enseignement et de recherche français ou étrangers, des laboratoires publics ou privés. 


\section{schemes}

\section{Nadine Turpin, Pierre Dupraz, Claudine Thenail, Alexandre Joannon, Jacques Baudry, Serge Herviou and Peter Verburg.}

Nadine Turpin and Serge Herviou, Cemagref UMR 1273 Métafort, 24 avenue des Landais - BP 50085 - 63172 AUBIERE cedex, France

Pierre Dupraz, INRA-ESR, 4 allée Bobierre-CS 61103-35011 Rennes cedex, France

Claudine Thenail, Alexandre Joannon and Jacques Baudry, INRA Unité SAD-Paysage, 65 rue de Saint-Brieuc-CS 84215-35042 Rennes cedex, France

Peter Verburg, Wageningen University and Research Centre, Laboratory of Soil Science and Geology, P.O. Box 37, 6700 AA Wageningen, The Netherlands

Corresponding author: Nadine Turpin, telephone + 33473440 634, fax +33473440 698, e-mail address nadine.turpin@cemagref.fr

\section{Abstract}

This paper analyses the potential effect of local agro-environmental policies in promoting multifunctionality in a rural landscape, with a two-scale modelling framework: a regional scale for food demand and a local scale for the forces driving land use. The framework has been designed in four steps. First, the relative influence of the driving factors on the current land use pattern has been analysed. Two scenarios are designed that vary the external demand for the total land use, and alter more or less quickly the specific location factors that drive the landscape pattern. The first scenario considers trends in the external and internal driving forces. The second relies both on totally decoupled farm subsidies and unregulated housing growth. In both scenarios a local agro-environmental policy is introduced and we compare its consequences with the previous scenario's landscape pattern. The third step consists of a modelling exercise that analyses the likely outcome of each scenario on the development of land use patterns on a local scale. Last, these landscape patterns have been translated into ecological indexes that assess the effect of the policy options on the multifunctionality of the local landscape.

Keywords : local agro-environmental policy, land use pattern, landscape, scenarios

\section{Introduction}

This paper analyses the impact of local agro-environmental policies on changes in rural landscapes and on the promotion of landscape multifunctionality. In rural areas close to urban fringes, the factors driving landscape evolution are the demand for housing (with their associated employment and service 
areas), the demand for agricultural products and the demand for preservation or restoration of natural areas and resources. These demands come from different stakeholders, who often have no way to coordinate themselves. Moreover, their different demands occur on different scales: the demand for agricultural products, including considerations like quantity, quality and food security, is expressed on a regional scale but more often at national or international scales. The demand for new housing is relatively localized, at least in the medium term, and neighbouring cities may compete to attract new inhabitants. A high quality environment is a public good, which has implications ranging from a local scale (protection of an endangered species, management of wildlife resources) to a world scale (climatic stability, management of migrating birds). Lastly, numerous policy responsibilities co-exist in rural areas, from European agricultural policies and the world market to local rural management policies, and they may not affect the rural areas in a totally consistent way.

The development of multifunctional agriculture is one way to reconcile this diversity of requirements from different people in society. The concept of multifunctional agriculture arose during the Rio Summit in 1992 from the observation that apart from the production of food and fibres, i.e. commodities, agriculture provides important social, environmental and economic functions to society. These functions manifest themselves in products that hitherto have been non-marketable (i.e. noncommodities). The institutional recognition of the multifunctional agriculture concept allows the remuneration of these additional functions. The notion of multifunctional agriculture is part of the justification for the Farming Guidance law adopted in France in 1999, and is also included in the preliminary assessments of the last orientation law adopted late in 2005. This concept is cited in the European Common Agricultural Policy (CAP) orientations defined during the Berlin Summit (1999). It is also currently debated at the international scale, in the Organisation for Economic Co-operation and Development (OECD) and World Trade Organisation (WTO) meetings, with a view to authorising some subsidies for farming activities (green box).

The diversity of the demands and of the scales at which they are expressed, and the multiplicity of decision levels, result in difficulties in assessing the potential impact of local policies (Schneeberger, Burgi et al., 2007). Existing literature often starts from a case study and focuses on specific topics such as the description of the debates and potential conflicts between the different stakeholders (Houghton, 2005), or the respective roles of local and regional policies on the adoption of systems that jointly supply public goods, or they try to describe how farmers' behaviour can influence the policy makers' (Vandermeulen, Verspecht et al.). The local competition for resource allocation between economic development and natural resource restoration is the most recent topic analysed in the literature (Jonas and Gibbs, 2003). Very few papers directly consider the ways in which a local policy can modify the evolution of landscapes and their different functions. The way a local policy can modify the trends in local landscape evolution is the main objective of the work presented here. 
To analyse how local policies can promote the multifunctionality of rural areas, we chose a two-scale modelling framework: a regional scale at which the demand for agricultural products is expressed, and a local scale that combines 1) the modelling of factors that drive land use and landscape organisation and 2) the design of prospective scenarios (Kelly, Sirr et al., 2004) including local policies. These local policies refer to two types of action levels: urban regulation and agro-environmental measures. The factors at work with urban area regulation are the reception facilities for new inhabitants (including new activities and new demands), the capacity to maintain farming activity, and different environmental conditions linked to urban area greening, fragmentation and organisation of agricultural landscapes (Carsjens and van der Knaap, 2002) or road traffic developments (Pauwels and Gulinck, 2002). Policies based on agro-environmental development refer mostly to the management of natural resources and especially to the expansion and linking together of green areas that provide favourable habitats for plants and animals and facilitate their movement (Burel and Baudry, 1999). All these functions are integrated into the landscape and participate in the multifunctionality of rural land.

The competition between the different land uses is analysed through the synergies and antagonisms between the different functions in a region. In contrast to Rounsevell et al. (2006), who used one simple criterion to rank the preferences for each land use type, we show that the local agroenvironmental policies can lead to a modification of the competition parameters of the different land use types and thus to evolution of the landscape.

The paper is organised as follows. Section 2 presents the 4-step framework designed to assess the effect of local policy options on the multifunctionality of the rural landscape. First, the influence of the driving factors on the current land use pattern is analysed. Two scenarios are designed that vary the external demand for the total land use, and alter more or less quickly the specific location factors that locally drive the landscape pattern. The first scenario considers trends in the external and internal driving forces. The second relies both on totally decoupled farm subsidies and unregulated housing growth. In both scenarios a local agro-environmental policy is introduced and we measure its consequences compared with the previous scenario's landscape pattern. The third step consists of a modelling exercise that analyses the likely outcome of each scenario on the development of land use patterns on a local scale. Lastly, these landscape patterns have been translated into ecological indexes that assess the effect of the policy options on the multifunctionality of the local landscape.

Section 3 describes the landscape patterns that result from the different options in each scenario after a simulation over a 15 -year period. Section 4 presents the ecological status resulting from these different landscape patterns and Section 5 presents conclusions. 


\section{Method}

To analyse how local policies can promote the multifunctionality of rural areas we constructed contrasting scenarios (see Sharma (2006) for a recent literature review). A scenario consists of a set of assumptions translated into a set of organised driving factors. In our case, these driving factors operate at two levels, the regional level for the global land requirements and the local level for specific location factors and local policies. These scenarios are based on the analysis of the past regional land use evolution and specific location factors. A reference scenario ("scO") is based on an analysis of trends from 1990 to 2000, which are projected forward to 2015. In a contrasting scenario ("scN") we assumed that the agricultural policy is totally de-coupled and that town planning is less regulated. Then we modified the driving forces of these two scenarios and added to each one a local agroenvironmental policy that is expressed through specific location factors and through a modification of the general demand of society in relation to rural landscapes ("scVO" and "scVN" scenarios).

The comparison between scenarios occurs in two steps. The first step is a modelling exercise that analyses the likely outcome of each scenario on the development of land use patterns on a local scale, using simulation models. The second step assesses the ecological effects of the landscape spatial organisation for each scenario.

\subsection{Regional land use and specific location factors}

The study area is located south-west of Paris, in the Centre region, Eure-et-Loir department. This area is part of the French wheat granary, and is subject to two main driving forces: the CAP policy, including the Water and Birds directives, and a demand for space and amenities from growing cities around the area Paris, Chartres and Orléans.

The current land use pattern has been derived from the Corine Land Cover coverage for the year 2000 and the French agricultural census for the same year. As a consequence, the analytical resolution is scaled at the pixel level ( $250 \mathrm{~m}$ width, one pixel covers $6.25 \mathrm{ha}$ ). The Corine Land Cover nomenclature describes precisely the non-agricultural use of land, but does not distinguish the different crops within the agricultural land use. We used the Avenue ${ }^{\circledR}$ "random" function to create a land use map including the different crops depicted in the agricultural census for each municipality. The main city of the region is Chartres, which is located in the NW of the area. There are several small villages scattered all over the area (see Figure 2 a.). Small forests border rivers. Urban areas and forest cover $10 \%$ of the zone, the remainder being farmland. The main crops are cereals (two thirds of the whole area), oil seeds and peas ( 7 and $8 \%$ of the whole area respectively), potatoes and vegetables $(4 \%)$, setaside and small areas of grassland, with very large cereal fields and smaller plots of oilseeds and peas. 
We determined the potential driving factors for land use from a literature review, a specific survey in a municipality in the area and interviews with local stakeholders. A recent European project, Scenar 2020, identified future trends and driving forces that will shape European agriculture and rural economy by 2020 (European Commission, 2007). This project concludes so far that rural areas are not stable; most of them are driven by urban economies rather than rural economies; land use in rural areas changes rapidly, shifting between commodities within the agricultural sector, between sectors, and between productive and fallow land. Moreover, in a recent literature review, Bush (2006) points out that the evolution of land use is analysed with the same framework whichever model is used: the demand for agricultural commodities (conditioned by the demand for food, economic growth, international markets and policies) drives a need for land use: depending on the production technologies available, this need in effect becomes a use of the bio-physical features and spatial limits of the modelled areas.

The driving factors that may explain the current land use pattern have been collected at different scales, from the life basin including several municipalities (Insee, 2003), to the pixel, through the data provided by the agricultural census at the municipality level. A local survey showed that, in a municipality located in the highly irrigated zone, the main drivers for cropping pattern and crop sequences at farm level are the physical characteristics of the fields (stoniness, field size and available water), the equipment and available labour force to irrigate the crops, and the various quotas and contracts at the farm level (Joannon, Bro et al., 2007). Because of the potentially big influence of equipment, irrigation potential and market structure for the various commodity outputs supplied, we designed the set of potential driving factors with emphasis on this type of information (see Table 1).

The influence of all these driving factors on the current land use has been assessed for the year 2000 using logistic regressions. This is a method commonly used to build probability maps for land use patterns in urban growth areas (Cheng and Masser, 2003; Fang, Gertner et al., 2005; Wu, 2002), or in areas with problems of deforestation or evolving agriculture (Geoghegan, Villar et al., 2001; Serneels and Lambin, 2001). With this method, the probability of occurrence of land use $Y$ in cell $j$ is estimated with a logistic function:

$$
\log \left(\frac{P\left(Y_{j}=1\right)}{1-P\left(Y_{j}=1\right)}\right)=\log \left(\frac{p_{i, j}}{1-p_{i, j}}\right)=\alpha+\alpha_{1} X_{1, j}+\alpha_{2} X_{2, j}+\ldots+\alpha_{n} X_{n, j}
$$

where $X_{i, j}$ is driving force $i$ in cell $j$. The major drawback of this binomial logistic function approach is that the different land use types are not i.i.d. ${ }^{1}$; we used a multinomial probit function to cope with the

\footnotetext{
${ }^{1}$ i.i.d.: independent and identically distributed
} 
fact that the different land use types can be correlated and non-identical, and we tested each land use type against all the others ${ }^{2}$, because these parameters are inputs for the CLUE-S model.

The statistically significant driving factors are depicted, for each land use type, in Table 1. An unexpected result of this analysis is that the municipalities that have the larger urban areas also provide most of the agricultural labour force. This situation reflects periurban agriculture near the city of Chartres (small farms with a large labour force), in contrast with rural municipalities with large cereal farms with not much labour. It is worthwhile noting that the share of urban areas between rural and periurban municipalities is not significant in our case study.

Cereals are driven first by the available agricultural labour force (-), by the location in the advice area of Orgères, the distance to a grain merchant (the cereal acreage declines with increasing distance from a merchant). Other factors such as the distance to a motorway junction or location in diversified or residential areas are of less influence. The other driving factors for cereals concern the percentage of irrigated area, the distance to national roads and a negative effect of flour mills.

Oil seeds and peas are traditionally grown as alternative crops to cereals in this area. These crops are sold for oil and cake for animals. The collection of raw crops is costly, but the transport of transformed products is rather cheap. This explains the importance of the distance to the animal feed factories in the specific factors that explain the presence of oil seeds and peas in the area.

Potatoes and vegetables are mostly located in irrigated areas and near packing sheds.

Table 1 : significant driving factors for the Beauce case study; grey cases show non-significant coefficients

\subsection{Scenario design}

The land use evolution scenarios have been designed while varying the total demand function according to several decoupling assumptions, using several urban growth assumptions, according to variation of specific location factors such as agricultural labour or the fraction of irrigated area. We also introduced a specific demand for environmentally-friendly crops in the Ogare ${ }^{3}$ zone (see Turpin $e t$ $a l .$, (2007) for a complete description of these scenarios).

\footnotetext{
2 the SAS procedure for this test is proc MCD, with the Multivariate Normal distribution correlated and nonidentical (option MP)

${ }^{3}$ The Ogare zone is a specific area in the study area, where local stakeholders try to promote the development of wildlife
} 
Scenario $\mathrm{O}$ represents the central scenario from the current French forecast. This scenario assumes that the forces that drive French people towards the rural areas will not change in the near future. For the national forecast group, this scenario should result in an increase of people living in these areas, a rural urbanisation (DATAR, 2003; Perrier-Cornet, 2004) and maybe an increase in local conflicts between different land use plans. This scenario assumes the current French decoupling options, mean demographic growth for the region (DATAR, 2003), and no local agro-environmental policy. This scenario assumes that past trends for specific location factors will continue.

The $\mathrm{N}$ scenario analyses the impact of fast urban growth. Indeed, the study area benefits from various advantages, like the proximity of Paris (1 hour), a dense network of roads and motorways, easy access to IT facilities and a diverse labour supply. Assuming an increase in competition between small regions, the study area can expect a large increase in population. We also assumed that the new inhabitants will want shopping centres in areas that provide rural amenities, such as space (Gude, Hansen et al., 2006). Moreover, the scenario follows total decoupling assumptions from Barkaoui and Butault (2004).

The two V scenarios combine several elements that should allow a better integration of the environment in the local development: starting from the two previous scenarios, we made the additional assumption that a local regulator tries to promote environmentally-friendly practices. This local policy will apply to a specific area, the Ogare zone, which is part of the study area (Figure $2 \mathrm{~b}$.).

\subsection{Step1: modelling exercise}

The modelling exercise is carried out using the land use allocation model CLUE-S (Verburg, 2006; Verburg, Soepboer et al., 2002), which allows multi-scale representation of the land use system. The model combines specific location factors at the local level (like suitability for each land use and spatial policies) with the evolution of land requirements at the regional level over a given period. The latter has been assessed with a French positive mathematical programming model designed at the regional level (Barkaoui and Butault, 2004). Of course, as the land requirements and the specific location factors are determined externally by the CLUE-S model, there are several ways to determine them, ranging from deductive to inductive procedures (Overmars, Verburg et al., 2007).

In the CLUE-S model, the probability of the occurrence of land use type $\mathrm{j}$ at location $\mathrm{i}\left(\mathrm{p}_{\mathrm{i}, \mathrm{j}}\right)$ depends on the suitability of the location for the land use type. The total probability of the allocation of land use type $\mathrm{j}$ at location $\mathrm{i}\left(\mathrm{P}_{\mathrm{i}, \mathrm{j}}\right)$ is influenced by the relative modification elasticity $\left(\lambda_{\mathrm{j}}\right)$ and the iteration parameter $\left(\alpha_{\mathrm{j}}\right)$ :

$$
P_{i, j}=p_{i, j}+\lambda_{j}+\alpha_{j}
$$


The iteration parameter $\alpha_{j}$ is used to modify the total probability of the individual land use types to reach the aggregated land use requirements on a regional scale as demanded. The first iteration starts with the same $\alpha_{j}$ value for all the land use types. The aggregated allocation of each land use type is compared with the total demand. For land uses having an allocated area greater than the demand, the parameter $\alpha_{j}$ is decreased and it is increased when the sum is smaller than the demand. The final value is determined iteratively. Moreover, location preferences and neighbourhood constraints can be introduced (Equation 2). These modify the total probability for land use $\mathrm{j}$ in year $\mathrm{t}$ depending on land use in neighbouring locations and other location preferences (like preferences coming from local taxes and subsidies) in year $\mathrm{t}-1$ :

$$
P_{i, j, t}=\left(1-\beta_{j}\right) p_{i, j}+\beta_{j} N_{j} L_{j, t-1}+w_{j} k_{i, j}+\lambda_{j}+\alpha_{j, t}
$$

Where:

$\beta_{j} \quad$ is a weight parameter for the neighbourhood effect for land use $j$

$N_{j} \quad$ is a matrix of neighbouring effects parameters for land use $\mathrm{j}$ (Verburg, Ritsema van Eck et al., 2004); this matrix describes the land uses $\mathrm{j}^{\prime}$ that influence $\mathrm{j}$, and the distance at which this influence operates.

$L_{j^{\prime}(t-1)}$ is the map of land use for the year $\mathrm{t}-1$

$w_{j} \quad$ is the weight for localisation preferences

$k_{i, j} \quad$ is the parameter preference for localisation of land use $j$ on location $i$; such additional location preferences may include the consequences on the actors' location preferences coming from taxes/subsidies for a specific land use or reflect a change in location suitability as defined in a scenario.

The modelling exercise provides the evolution of land use over a 15 year period for each scenario, with a $250 \mathrm{~m}$ resolution. Special attention has been paid to potential path-dependence in the model: because the initial land use conditions are uncertain at the pixel level (they were assessed randomly in each municipality), there was a potential error of propagation and/or bifurcation (Verburg, 2006). To reduce this risk, we started with ten different initial land use condition sets, and we examined, for each scenario, the trajectories of modelled land use change. For all the scenarios, after the third year of simulation, the trajectories for each set of initial conditions converge and thus we assumed that we can rely on our simulations, despite the inaccuracy of our initial condition assumptions.

Last, the landscape spatial organisation after 15 years of simulation is translated into indicators depicting the ecological status of the area.

\subsection{Step2: assessing the ecological effects of each scenario}

We made the following assumptions: 
1. partridges nest mostly in cereal fields (more than $50 \%$ of nests) and in the landscape's linear features (Bro, Reitz et al., 2000a); in the fields, $75 \%$ of the nests are located close to the edge (less than 20 meters) (Bro, Reitz et al., 2000a; Reist, E. Le Goff et al., 2002).

2. for feeding, the partridge prefers some diversity in the cropping pattern; the diversity of crops should provide hiding places in all seasons. The survival rate and the partridge density are higher in fine-grain landscapes, where the crop patches are smaller. From April to September, the partridge prefers cereals, followed by rape and peas, then row crops (Guyon, 2005). The presence of all these crops within a small area may favour partridge populations.

3. carnivorous predation is more important near woodland (Guyon, 2005; Reitz and Mayot, 1999).

4. the partridge is a farmland bird (Bro, Reitz et al., 2005a; Reitz, 2003) that generally avoids human habitation.

To estimate the influence of these various assumptions on the landscape scale, we designed an ecological indicator and measured its values with the CHLOE model (Baudry, Boussard et al., 2005). First, we assumed that the mean living area for a pair of birds is about 60 ha (9 pixels). On each $3 * 3$ pixel window in the area, we measured scores N1, N2 and N3, where:

- N1 is the proportion of cereal field margins (proportion of pairs of pixels that includes a cereal and another crop),

- N2 is the proportion of total field margins represented by the setaside grass-strips,

- N3 is the Shannon index of the window (this index represents the diversity of the pairs of adjacent pixels of agricultural land use).

The lack of data about partridge density in the studied area prevented us to validate these score against observation of birds every each 60 ha. In this sense, the scores are rather coarse. However, they are designed according to consistent rules. It has been shown that agricultural changes over the past 40 years have been the main cause of the decline in farmland birds, including the grey partridge (Robinson and Sutherland, 2002; Siriwardena, Baillie et al., 1998). Nevertheless, our indicator doesn't take into account all the factors that could affect grey partridge populations. In particular, the dynamics of the predator populations are not considered, while predation can be a major cause of mortality, especially during the breeding period when the hens cannot move (Bro, Reitz et al., 2005b). Moreover, crop management practices also influence grey partridge populations:

- irrigation and harvesting implements can destroy the nests (Birkan, Serre et al., 1990; Bro, Reitz et al., 2000b),

- pesticide applications: insects are a main food source for the young chicks, and insecticide applications reduce their availability in the soil, while herbicide applications reduce insect habitats (Rands, 1985; Serre and Birkan, 1985), 
- soil tillage: a recent review by Cunningham et al. (Cunningham, Chaney et al., 2004) has shown that non-inversion tillage instead of a conventional ploughing could be effective in increasing insect availability in the soil.

The difficulty is that all these crop management practices cannot easily be observed on satellite images or aerial photos, and neither are they generally available from censuses. This is why we did not take them into account. For that reason, our indicator should be used with caution.

This indicator has been based on grey partridge requirements since it is a symbolic bird with a game value in our study area, but other bird species - the common quail (Coturnix coturnix) or the skylark (Alauda arvenis) among others- have similar requirements (Barbier, 2001; Guyomarc'h, 2003). Moreover, this indicator also allows also us to evaluate the state of other environmental factors. Indeed, it gives an evaluation of agricultural landscape heterogeneity, which has been identified as a key factor in farmland biodiversity (Benton, Vickery et al., 2003). It has also been shown that cropland heterogeneity affects the water fluxes along with the nutrients and associated soil sediments, and hence the water quality and the rate of runoff and erosion (Beaujouan, Durand et al., 2001; Souchere, Cerdan et al., 2001).

To decide whether a window was suitable or not we adopted a crude approach: it was suitable due to high crop edge number when $\mathrm{N} 1>0.5$ : for suitability for agro-environmental measures we took $\mathrm{N} 2>0.25$ and for both, a combination of the two suitability measures. We also measured the connectivity among suitable pixels (i.e. number of adjacent suitable ones); large areas of continuous suitability are better than fragmented suitable patches, because they permit the movement of partridges.

\section{Land use evolution in contrasting scenarios}

\subsection{Scenario 0}

This scenario assumes that the human population density remains constant throughout the period (in other words, people do not tend, on average, to increase the size of their houses). Population grows according to the French forecast group assumption of $0.478 \%$ per year (DATAR, 2003). As a consequence, the total agricultural area decreases. The regional demand for agricultural land evolves according to Barkaoui and Butault's predictions for the region (2004), with the current French decoupling options. With their assumptions, the vegetable and potato acreage increases slowly $(0.1 \%$ per year); cereals and peas also increase, as do oil seeds, whilst the area of grassland and setaside decreases (Figure 1 a.). It is worthwhile noting that no increased demand for biofuel has been considered so far.

Moreover, this scenario assumes that the specific location factors such as availability of farm labour, irrigated area and machinery are kept constant over the simulation period. 
With this scenario, urban areas expand mostly around the main city. However, the evolution of agricultural land use is rather limited: the most noticeable change is a decrease in oil seeds, more apparent in the northern part of the area, while vegetables decrease mostly in the southern part (Figure 2 c.).

Figure 1: evolution of the agricultural demand, a. scenario $O, b$. scenario $N$, c. scenario VO and d. scenario VN

Figure 2: land use in the Beauce case study, a. initial land cover (year 0), b. location of the Ogare area, c. to $f$. land use after 15 years of simulations (c. scenario $O$, d. scenario $N$, e. scenario VO and $f$. scenario VN)

\subsection{Scenario $\mathrm{N}$}

Scenario $\mathrm{N}$ depicts a de-regulation of town planning rules: the total built-up area increases at $5 \%$ per year because of an increase in the population, assuming that the area benefits from its advantages and that the new inhabitants build larger houses than the existing ones. The evolution of the regional agricultural area is driven by the increase in the urban area and by the total decoupling assumption in the Barkaoui and Butault (2004) model: the pea area increases at a slower rate than for scenario O; the oil seed area decreases more quickly and the cereal area decreases because of urban sprawl (Figure 1 b.).

Scenario $\mathrm{N}$ predicts an increase in the built-up area in the northern part of the case study area, where the conurbation experienced major growth in past decades and again recently (Figure $2 \mathrm{~d}$.). There is no decline of built-up area in the declining conurbations, because the demand for forests does not evolve ${ }^{4}$. (The growth in built-up area is mainly in the suburbs of Chartres, the main city in the area, and to surrounding pluripolarised municipalities.

Competition, in the northern part of the study area favours built-up areas rather than oil seed crops, and so the decline in oilseed area in the south is slower than for scenario $\mathrm{O}$.

\subsection{Scenario V}

The agro-environmental scheme proposes measures aiming at: (i) the establishment of grass strips along margins of field devoted to cereals, oilseeds or peas, (ii) encouraging a patchwork of different crops (to avoid large areas of monoculture), and (iii) increasing the area of forest. The schemes are implemented in two steps: the first 5 years are devoted to an increase of the total adoption area (by this time the agro-environmental coverage should be $75 \%$ of the Ogare zone), while the remaining 10 years are devoted only to maintenance (Figure $1 \mathrm{c}$.). For modelling the introduction of the AES, two

\footnotetext{
${ }^{4}$ abandoned built-up areas can only be used to plant forest
} 
additional land use categories are considered: 'env1' are cereals with grass strips that favour partridge nesting and 'env2' are oilseeds with the same kind of grass strips. For the first five years of the scheme, the land requirements for these two land use types increase. During this period urban zones and woodland areas for recreation are also expected to increase. From the $6^{\text {th }}$ to the $15^{\text {th }}$ year, only the requirements for urban zones increase, mostly at the expense of cereals. Neighbourhood constraints have been added: new urban zones are allowed to be built at least one pixel $(250 \mathrm{~m})$ away from existing urban zones and large areas with the same agricultural land use type are disallowed. To represent the region's specific stimulation of land use types 'env1' and 'env2' as part of the Agroenvironmental Scheme (AES), the allocation of these land use types has been confined to the Ogare zone.

The adoption of agro-environmental use of land as a consequence of the increase in the demand for this land use during the first five years of the scenario is represented by aggregates of pixels, the neighbourhood constraints being the most active. After 15 years we observe an additional preferential use of oil seeds and peas in the Ogare zone, these crops being grown less in the south of the study area (Figure 2 e.).

\subsection{Scenario VN}

Figure $2 \mathrm{f}$. depicts the evolution of the simulated land use pattern for scenario VN. At the end of the 5year period devoted to expansion of the AES, urban sprawl occurred, as expected, mostly around the main city. After this period, the NW part of the Ogare zone, which is more favourable for oilseeds, is totally devoted to a patchwork of cereals and grass strips (env1), oilseeds and grass strips (env2) and some peas. In this zone, all the candidate fields are converted to the agro-environmental measures. The NE part of the Ogare zone develops differently, with a mixture of cereals (non-AES), cereals and grass strips (env1) and peas. Though the adoption of the AES is lower than in the north, the living conditions for partridge are greatly improved, with a higher than expected fragmentation of the landscape. This is due to the special measures that favour a patchwork of different crops in association with the growing of an env1 crop, even if it is surrounded by unconverted fields. Lastly, the piece of the Ogare zone located from SW to NE shows a patchwork of new groves, converted cereals and oilseeds (env1 and env2 crops), peas, vegetables and grassland areas. The impact of the AES is greater in this area.

After ten years of scheme maintenance despite the increasing urban pressure (Figure $2 \mathrm{f}$.), occurrence of urban sprawl is mostly prevented in the Ogare zone, except in the SE where the AES has been less adopted in the previous period. The increase of the urban area occurred in the northern part of the zone, mostly around the main city and close to a major road. It should be noted that one municipality in the north of the zone witnessed substantial urban development. This municipality combines several advantageous factors - a motorway junction and nearby landscape amenities (forests and newly 
designed landscape in the AES). But the nearer municipalities, which are also close to the same motorway junction, do not experience the same sprawl. In the same way, in the western part of the zone, despite a lack of major roads, urban areas increase close to a forest.

\section{From land use to ecological indicators}

The diversity of crops in a window (assessed with N3, the Shannon index of the window) represents the lower bound for interface share. In other words, the higher diversity is, the higher probability to have pairs of pixels including a cereal and another crop: the indexes N1 and N3 are not independent. However, N1 and N2 are independent, so we focused on the two main components that may affect landscape suitability for partridges: crop edges and grassy strips: (agro-environmental measures).

Table 2: number of unsuitable and suitable windows for partridges and connectivity (number of adjacent windows of the same type) between suitable windows for different scenarios

Table 2 suggests that while suitability due to crop edges alone did not vary much between scenarios, suitability due to both effects (crop edges and grassy strips) varied widely, mostly because no agroenvironmental measure is proposed in scenarios $\mathrm{O}$ or $\mathrm{N}$. We observed the same pattern for connectivity, it was low for agro-environmental measures and higher for crop edges. In this case, the $\mathrm{N}$ scenario did not constantly increase the area of suitable habitat for partridges. Although similarities showed up between scenarios, the spatial distribution of habitats was somewhat different (Figure 3).

Figure 3: suitability for grey partridge for the different scenarios a) scenario $O, b$ ) scenario $N, c$ ) scenario VO, d) scenario $V N$

\section{Conclusion}

Assessing ecological quality of a landscape from land use patterns is not a straightforward exercise for three main sets of reasons mentioned above: 1) land use patterns in most cases, as here, are only land cover patterns and do not integrate cropping techniques that may considerably change habitat quality, 2) ecological processes are scale-dependent, so map resolution exerts a strong influence on the results (Suarez-Seoane and Baudry, 2002), 3) the ecological requirements of the different species, both in terms of habitat and spatial configuration, are different, so heterogeneity of habitat quality may only mean that different species may coexist in an area. Nevertheless, amount of habitat for a given species or set of species and connectivity among suitable habitats are common measurements in landscape ecology to assess different scenarios of land use change (Baker, Hulse et al., 2004; Baudry, Burel et al., 2003). 
The simulation exercise performed for this paper consists of an exploration of the way a local agroenvironment policy can modify changes in a rural landscape and its multifunctionality. An efficient local policy should be able to modify the behaviour of the agents, in our case those who modify the land use, and at the same time consider that these agents are under the influence of multi-level driving forces and policies. In other words, the different land use types are in competition at each specific location, while local and regional driving forces tend to modify the competition rules. With this representation, it is possible to analyse the most probable evolution of the landscape and of the different functions at the landscape level, and to determine how a local policy that operates through specific location factors and through a global demand for land use can have an influence on the area where it is applied, and on the whole region.

The main advantage of the approach is to show how different combinations of preference factors can lead to identical land use at specific places: this is especially evident in the VN scenario in places where local amenities are shown to be able to compensate for poorer transport facilities. Moreover, the suitability of a specific area for partridges results from combinations of several landscape features, and because each of these feature can be driven by several combinations of preference factors, the analysis based on scenarios with a modelling exercise is revealed to be well able to clarify and simplify this multi-level, spatially specific phenomenon.

The approached revealed two main drawbacks: first, we introduced as input to the CLUE-S model simulations of the regional demand for the different land use types, these simulations being the result of a balance between several competing regions. If, as suggested by the modelling results, a local policy is able to modify the competition parameters between the regions, a totally rigorous analysis would loop information between the two models. In our analysis, we only performed a sequential modelling process but more interesting information would have been provided with an iterative procedure.

The second limitation of the analysis deals with the design of the local policy: although the simulations assess the different zones where the adoption of the policy is most probable and the analysis of the competition parameter provides information on the level of incentive required for the adoption of the policy, the framework does not provide practical information about the cost of effective implementation. Would it be greater than the expected benefits of the policy?

\section{Acknowledgements}

The authors thanks the participants at the Workshop on Understanding Relations in Nature and Economy, an Application to the Rural Countryside, 31 May - 2 June 2007, Wageningen, The Netherlands, for their helpful comments. 


\section{References}

Baker, J. P., Hulse, D. W., Gregory, S. V., White, D., Sickle, J. V. et al., 2004. Alternative futures for the Wilamette river basin, Oregon. Ecological Applications, 14(2), 313-324.

Barbier, L., 2001. Elements for a skylark (Alauda arvensis) management plan. Game and Wildlife Science, 18, 45-83.

Barkaoui, A. and Butault, J.-P., 2004. Impacts sur l'offre des régions françaises des différentes options de la réforme de la PAC de 2003. INRA Sciences sociales, 4-5(03), 6.

Baudry, J., Boussard, H. and Schermann, N., 2005, Chloe 3.0 : Freeware of multi-scales analyses on ASCII raster files. INRA SAD-Armorique, Rennes.

Baudry, J., Burel, F., Aviron, S., Martin, M., Ouin, A. et al., 2003. Temporal variability of connectivity in agricultural landscapes: Do farming activities help ? Landscape Ecology, 18(3), 303-314.

Beaujouan, V., Durand, P. and Ruiz, L., 2001. Modelling the effect of the spatial distribution of agricultural practices on nitrogen fluxes in rural catchments. Ecological modelling, 137, 93105.

Benton, T. G., Vickery, J. A. and Wilson, J. D., 2003. Farmland biodiversity: is habitat heterogeneity the key? . Trends in Ecology and Evolution, 18, 182 - 188.

Birkan, M. G., Serre, D., Pelard, E. and Skibnienski, S., 1990, Effects of irrigation on adult mortality and reproduction of gray partridge in a wheat farming system. In: R. E. Warner and S. J. Brady K.E. Church (Ed.), Perdix V: gray partridge and ring-necked pheasant workshop. Kansas Department of Wildlife and Parks, Emporia, pp. 257-271.

Bro, E., Reitz, F., Clobert, J. and Mayot, P., 2000a. Nest-site selection of grey partridge (Perdix perdix) on agricultural lands in north-central France. Game and Wildlife Science, 17, 1-16.

Bro, E., Reitz, F., Clobert, J. and Mayot, P., 2000b. Nesting success of grey partridges (Perdix perdix) on agricultural land in North-Central France, relation to nesting cover and predator abundance. Game and Wildlife Science, 17, 199-218.

Bro, E., Reitz, F. and Landry, P., 2005a. Grey partridge population status in central northern France: spatial variability in density and 1994-2004 trend. Wildlife Biology, 11, 31-42.

Bro, E., Reitz, F., Migot, P. and Arroy, B., 2005b. Conservation de la faune sauvage et conflits sociaux : La Perdrix grise et le Busard Saint-Martin dans le Centre-Nord de la France. Faune Sauvage, 256 42-56.

Burel, F. and Baudry, J., 1999, Ecologie du paysage: concepts, méthodes et applications. Lavoisier, Paris.

Busch, G., 2006. Future European agricultural landscapes--What can we learn from existing quantitative land use scenario studies? Agriculture, Ecosystems \& Environment, 114(1), 121140.

Carsjens, G. J. and van der Knaap, W., 2002. Strategic land-use allocation: dealing with spatial relationships and fragmentation of agriculture. Landscape and Urban Planning, 171-179.

Cheng, J. and Masser, I., 2003. Urban growth pattern modeling: a case study of Wuhan city, PR China. Landscape and Urban Planning, 62(4), 199-217.

Cunningham, H. M., Chaney, K., Bradbury, R. B. and Wilcox, A., 2004. Non-inversion tillage and farmland birds: a review with a special reference to the UK and Europe. Ibis, 146 (2), $192-$ 202.

DATAR, 2003. Quelle France rurale pour 2020 ? Contribution à une nouvelle politique du développement durable, DATAR, Paris.

European Commission, 2007. Scenar 2020 - scenario study on agriculture and the rural world, European Commission, Directorate General Agriculture and Rural Development, Directorate G Economic analysis and evaluation, Directorate G4 evaluation of measures applicable to agriculture.

Fang, S., Gertner, G. Z., Sun, Z. and Anderson, A. A., 2005. The impact of interactions in spatial simulation of the dynamics of urban sprawl. Landscape and Urban Planning, 73(4), 294-306.

Geoghegan, J., Villar, S. C., Klepeis, P., Mendoza, P. M., Ogneva-Himmelberger, Y. et al., 2001. Modeling tropical deforestation in the southern Yucatan peninsular region: comparing survey and satellite data. Agriculture, Ecosystems \& Environment, 85(1-3), 25-46.

Gude, P. H., Hansen, A. J., Rasker, R. and Maxwell, B., 2006. Rates and drivers of rural residential development in the Greater Yellowstone. Landscape and Urban Planning, 77(1-2), 131-151. 
Guyomarc'h, J. C., 2003. Elements for a common quail (Coturnix c. coturnix) management plan. Game and Wildlife Science, 20, 1-92.

Guyon, J., 2005. Influence de l'hétérogénéité du paysage sur l'utilisation de l'espace et l'interaction habitat-prédation - Exemple de la perdrix grise en grande plaine céréalière, Thèse de doctorat en Ecologie, Rennes 1, France.

Houghton, J., 2005. Place and the implications of 'the local' for sustainability: an investigation of the Ugu District Municipality in South Africa. Geoforum, 36(4), 418-428.

Insee, 2003. Structuration de l'espace rural : une approche par les bassins de vie, rapport de l'INSEE (avec la participation de IFEN, INRA, SCEES) pour la DATAR, Paris.

Joannon, A., Bro, E., Thenial, C., Baudry, J. and LeCoeur, D., 2007. How the management of crop location at the farm level could influence farmalnd bird biodiversity. A study in a a*cash crop area, Beauce, France. working paper, 23.

Jonas, A. E. G. and Gibbs, D. C., 2003. Changing Local Modes of Economic and Environmental Governance in England: A Tale of Two Areas. Social Science Quarterly, 84(4), 1018-1037.

Kelly, R., Sirr, L. and Ratcliffe, J., 2004. Futures thinking to achieve sustainable development at local level in Ireland. Foresight, 6(2), 80-90.

Overmars, K. P., Verburg, P. H. and Veldkamp, T., 2007. Comparison of a deductive and an inductive approach to specify land suitability in a spatially explicit land use model. Land Use Policy, In Press, Corrected Proof.

Pauwels, F. and Gulinck, H., 2002. Changing minor rural road networks in relation to landscape sustainability and farming practices in West Europe. Agriculture Ecosystems \& Environment, 77, 95-99.

Perrier-Cornet, P., 2004. L'avenir des espaces ruraux français. Futuribles, 299, 77-95.

Rands, M. R. W., 1985. Pesticide use on cereals and survival of Grey Partridge chicks : a field experiment. Journal of applied ecology, 22, 49-54.

Reist, F., E. Le Goff and Fuzeau, M., 2002. Landscape selection by grey partridge (Perdix perdix) for nesting in the fields of french cereal agrosystems. Game and Wildlife Science, 19, 209-220.

Reitz, F., 2003. Le statut communal de la perdrix grise et de la perdrix rouge en France : résultats d'une enquête. Faune Sauvage, 258, 25-33.

Reitz, F. and Mayot, P., 1999, Effects of habitat characteristics on the predation risk of the grey partridge, XXIVth IUGB Congress, Greece, pp. 248-258.

Robinson, R. A. and Sutherland, W. J., 2002. Post-war changes in arable farming and biodiversity in Great Britain. Journal of Applied Ecology, 39, 157-176.

Rounsevell, M. D. A., Berry, P. M. and Harrison, P. A., 2006. Future environmental change impacts on rural land use and biodiversity: a synthesis of the ACCELERATES project. Environmental Science \& Policy, In Press, Corrected Proof.

Schneeberger, N., Burgi, M., Hersperger, A. M. and Ewald, K. C., 2007. Driving forces and rates of landscape change as a promising combination for landscape change research--An application on the northern fringe of the Swiss Alps. Land Use Policy, 24(2), 349-361.

Serneels, S. and Lambin, E. F., 2001. Proximate causes of land-use change in Narok District, Kenya: a spatial statistical model. Agriculture, Ecosystems \& Environment, 85(1-3), 65-81.

Serre, D. and Birkan, M., 1985. Incidence de traitements insecticides sur les ressources alimentaires des poussins de perdrix grises (Perdix Perdix L.) dans un agrosysteme de Beauce. Gibier Faune Sauvage, 4, 21-61.

Sharma, T., Carmichael, J. and Klinkenberg, B., 2006. Integrated modeling for exploring sustainable agriculture futures. Futures, 38(1), 93-113.

Siriwardena, G. M., Baillie, S. R., Buckland, S. T., Fewster, R. M., Marchant, J. H. et al., 1998. Trends in the abundance of farmland birds: a quantitative comparison of smoothed Common Bird Census indices. Journal of Applied Ecology, 35, 24-43.

Souchere, V., Cerdan, O., Y. Le Bissonnais, Couturier, A., King, D. et al., 2001, Incorporating surface crusting and its spatial organization in runoff and erosion modelling at the watershed scale. In: D. E. Stott R. H. Mohtar \& G. C. Steinhardt (Ed.), Sustaining the Global Farm, selected papers from the 10th International Soil Conservation Organization Meeting, May 24-29, 1999, Purdue University pp. 888-895.

Suarez-Seoane, S. and Baudry, J., 2002. Scale dependence of spatial patterns and cartography on the detection of landscape change. Relationships with species' perception. Ecography, 25, 499511. 
Turpin, N., Dupraz, P., Thenail, C., Joannon, A., Baudry, J. et al., 2007, Landscape organisation and multifunctionality in the Beauce plain at local and regional scales, a scenario analysis with the CLUE-S model, Workshop on understanding relations in nature and economy, an application to the rural countryside, Wageningen, The Netherlands, pp. 16 p.

Vandermeulen, V., Verspecht, A., Van Huylenbroeck, G., Meert, H., Boulanger, A. et al., 2006. The importance of the institutional environment on multifunctional farming systems in the periurban area of Brussels. Land Use Policy, In Press, Corrected Proof.

Verburg, P. H., 2006. Simulating feedbacks in land use and land cover chang models. Landscape Ecol, 21, 1171-1183.

Verburg, P. H., Ritsema van Eck, J. R., de Nijs, T. C. M., Dijst, M. J. and Schot, P., 2004. Determinants of land-use change patterns in the Netherlands. Environment and Planning B: Planning and Design, 31(1), 125-150.

Verburg, P. H., Soepboer, W., Veldkamp, A., Limpiada, R., Espaldon, V. et al., 2002. Modeling the spatial dynamics of regional land use: the CLUE-S model. Environmental management, 30(3), 391-405.

Wu, F., 2002. Calibration of stochastic cellular automata: The application to rural-urban land conversions. International Journal of Geographical Information Science, 16(8), 795-818. 
a.
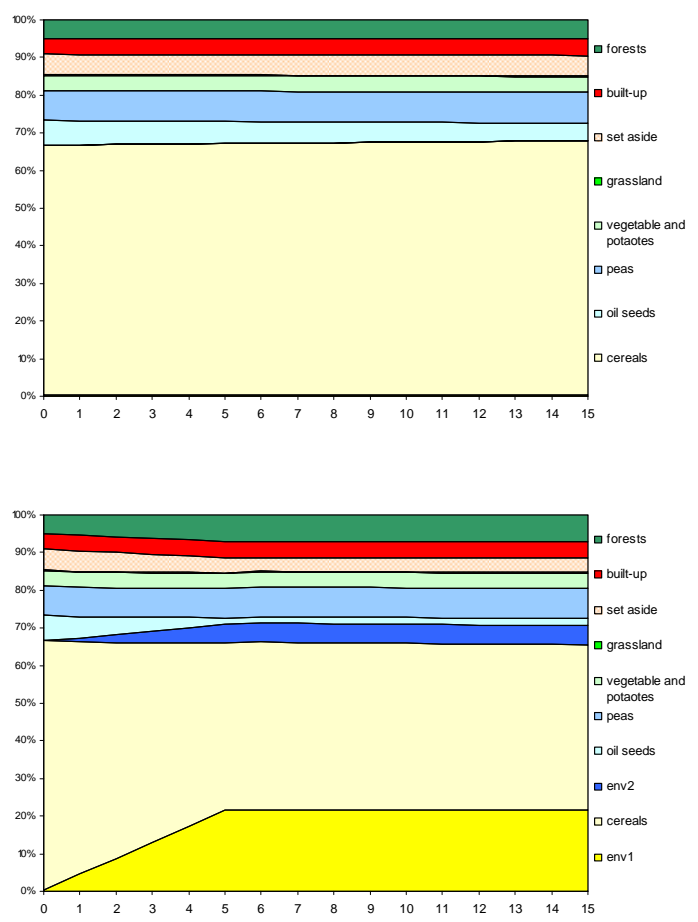

c.

Figure 1.

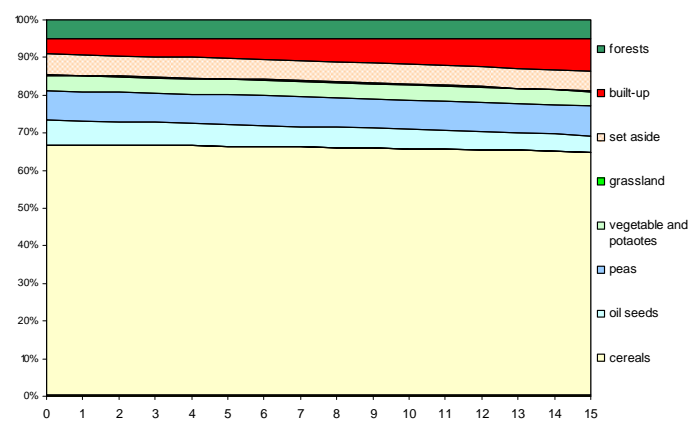

b.

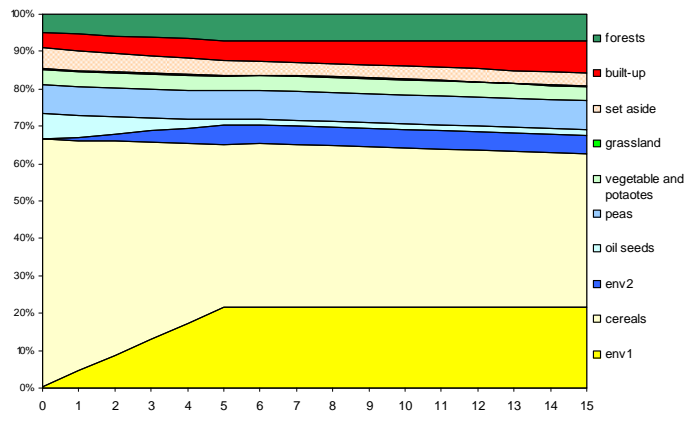

d.

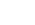




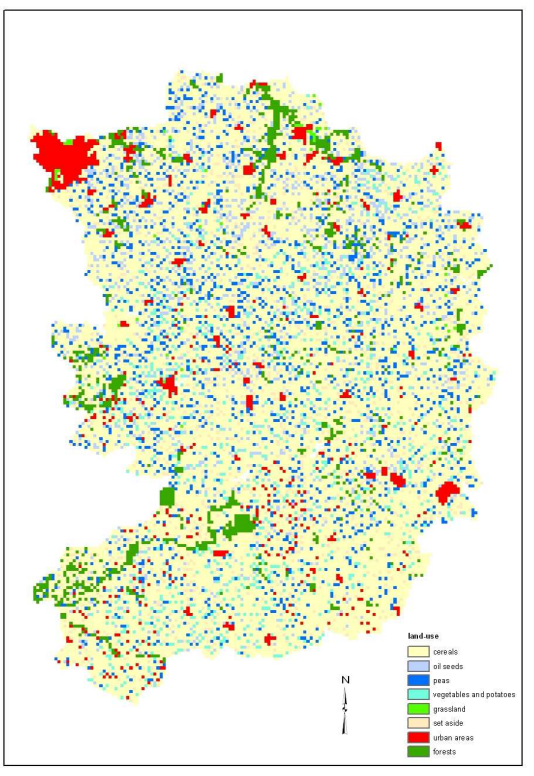

a.

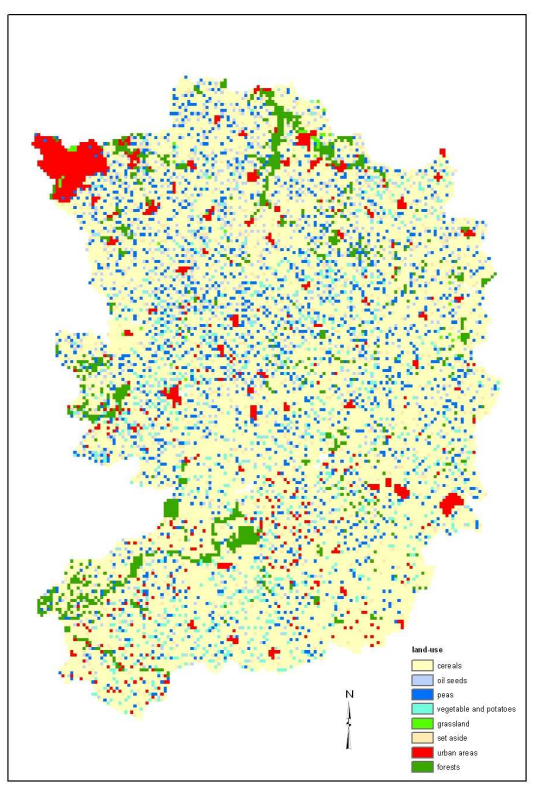

c.

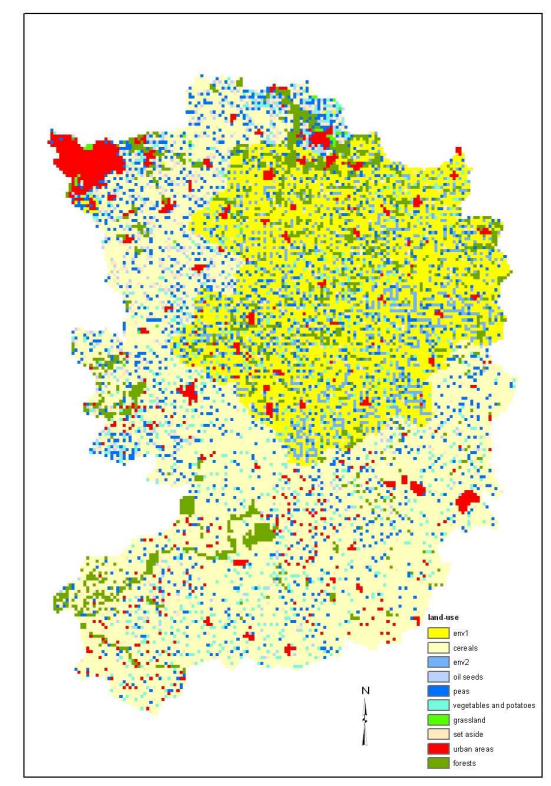

e.

Figure 2.

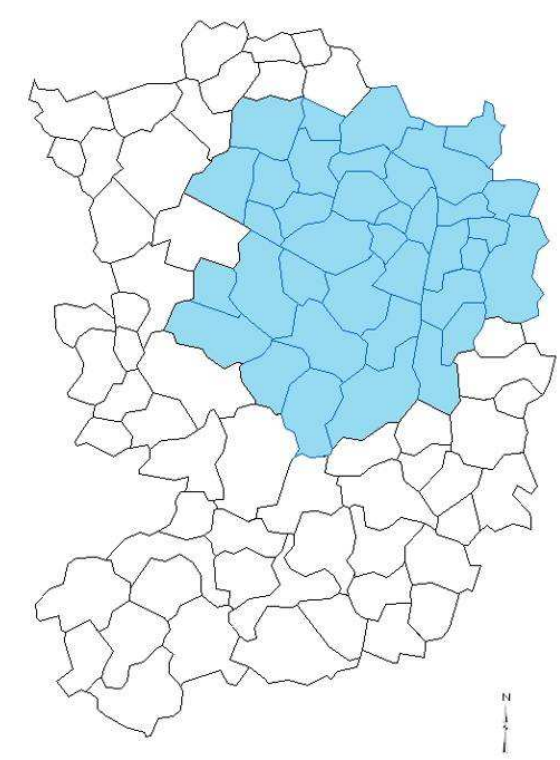

b.

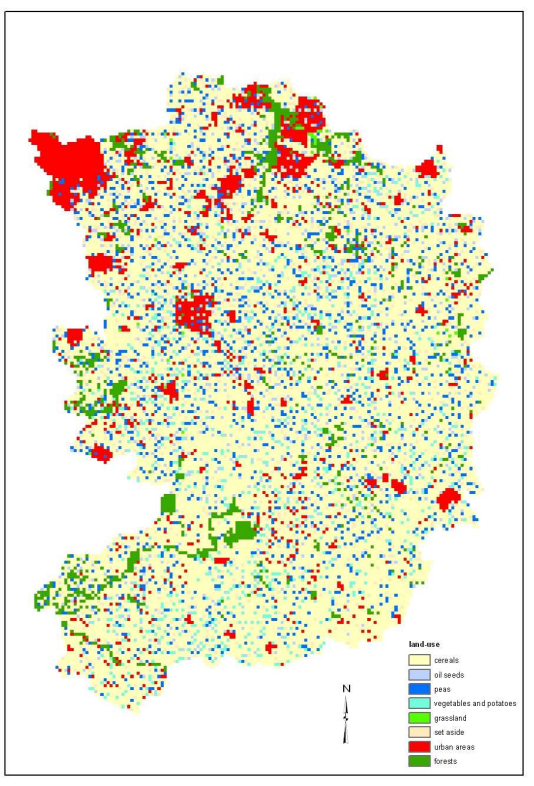

d.

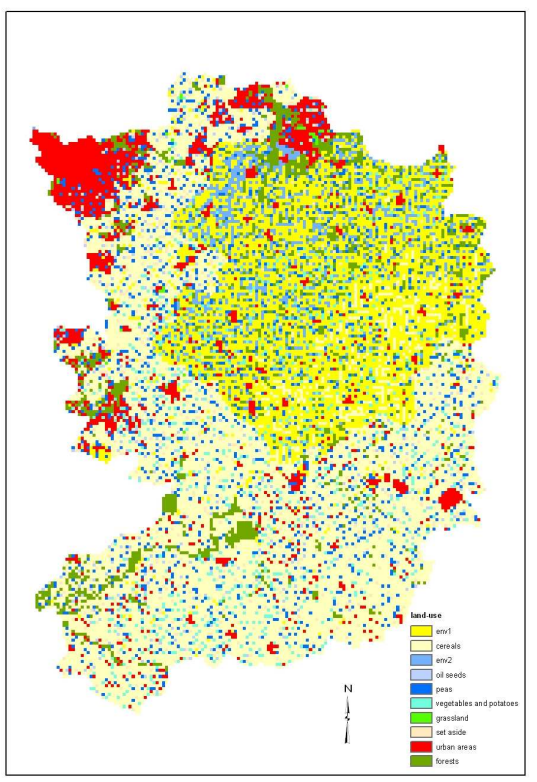

f. 


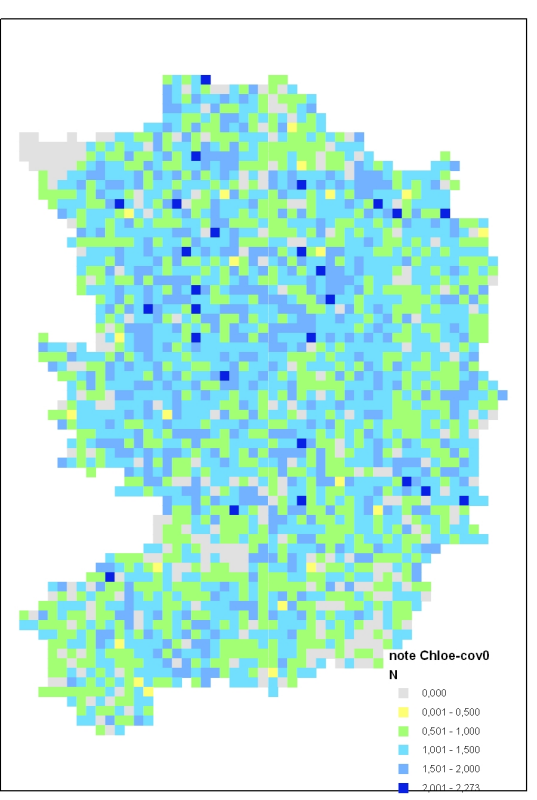

a.

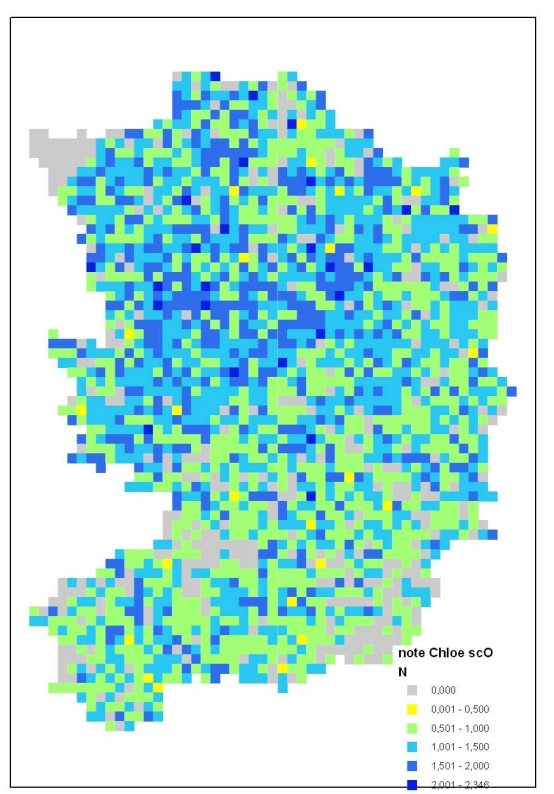

b.

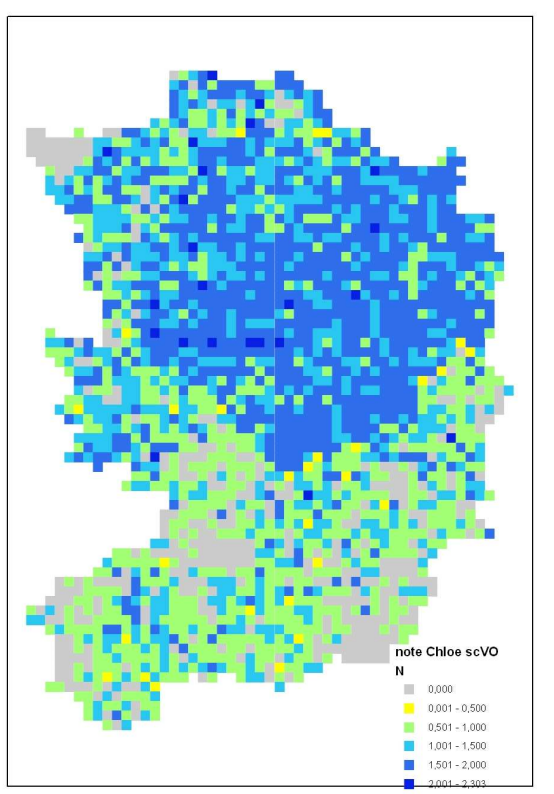

d.

Figure 3.

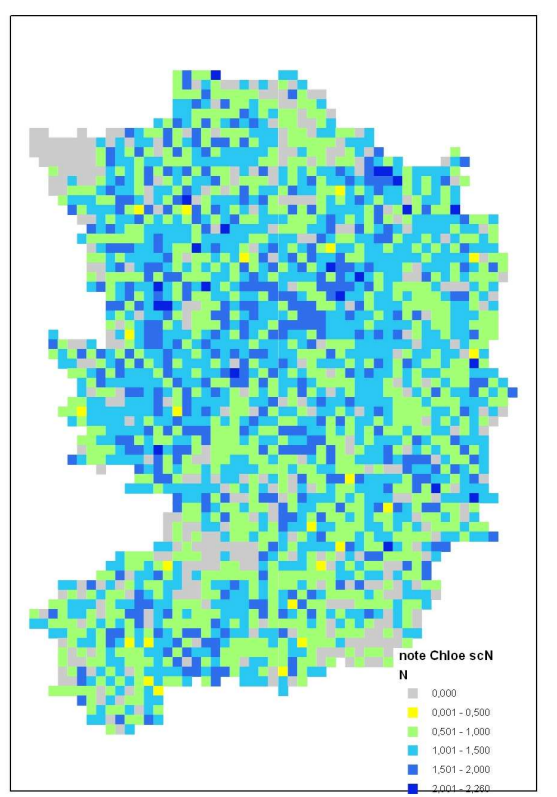

c.

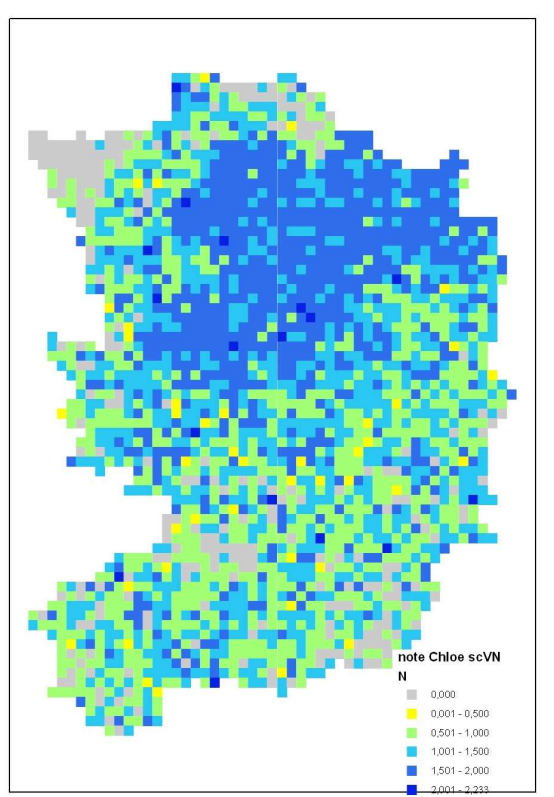

e. 
a.

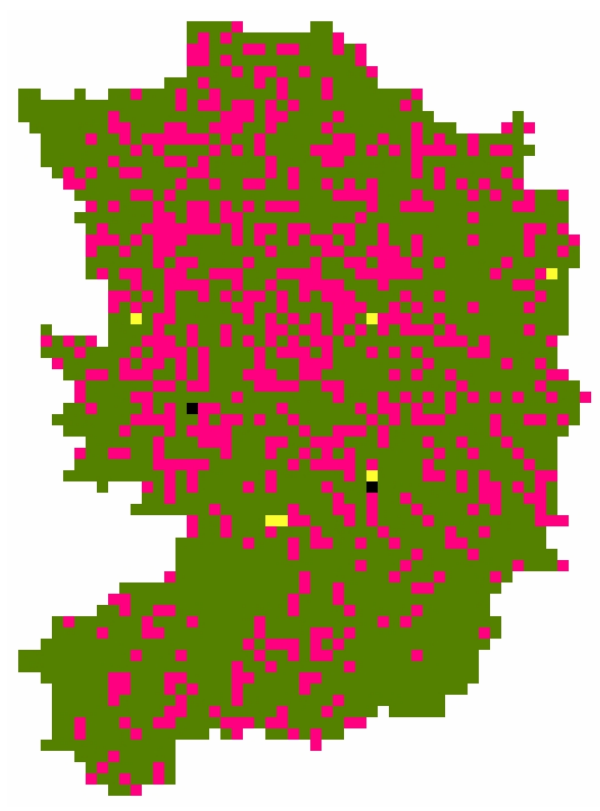

c.

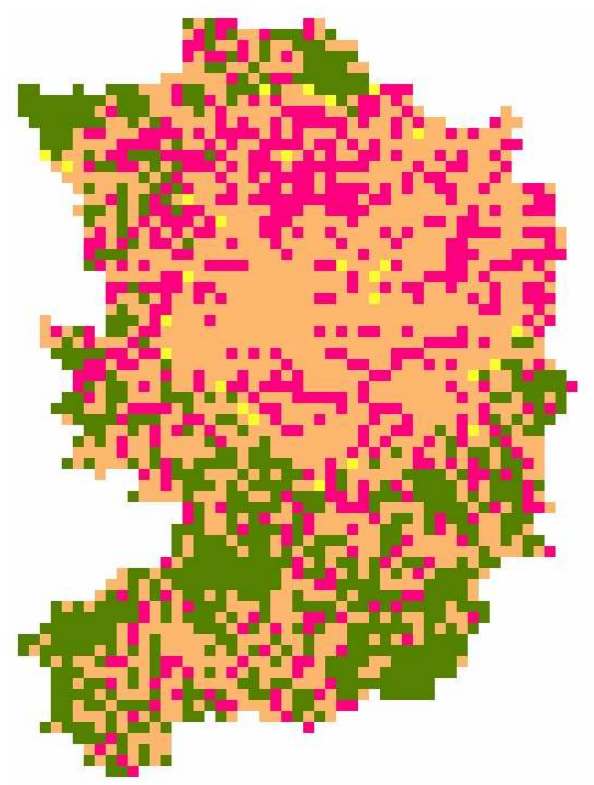

Figure 4. b.
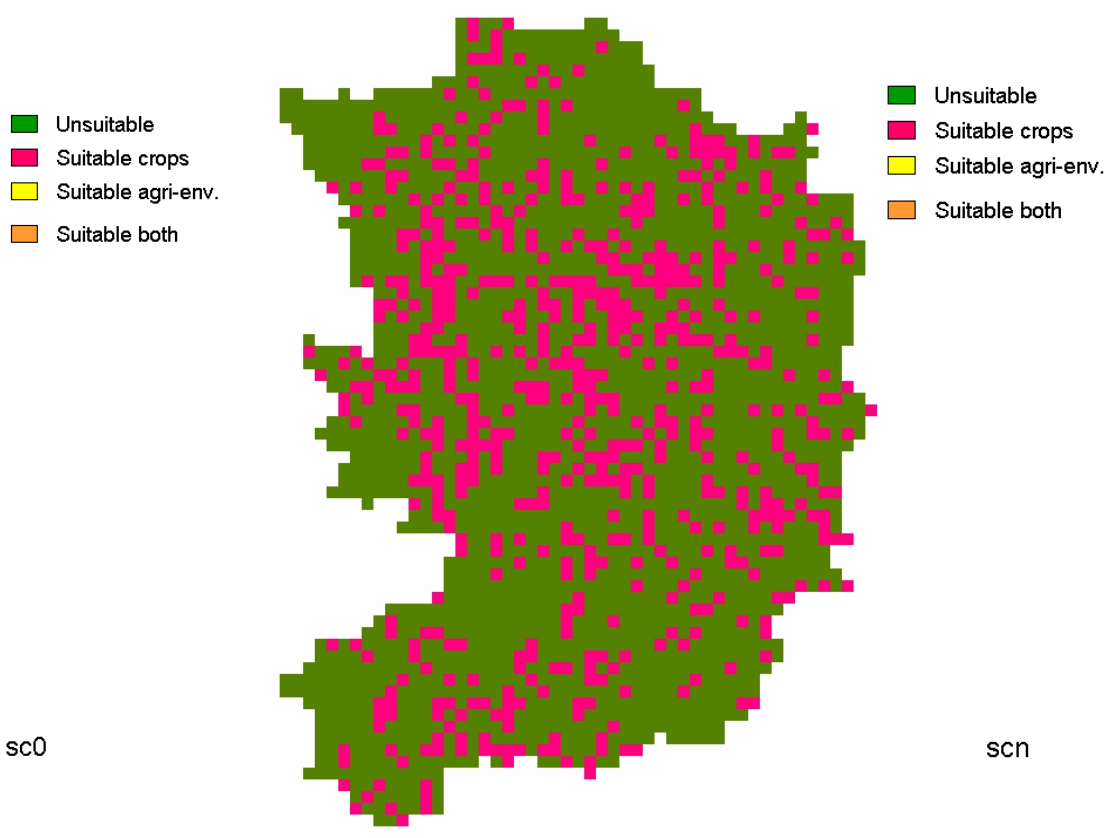

d.

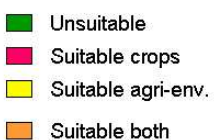

scvo

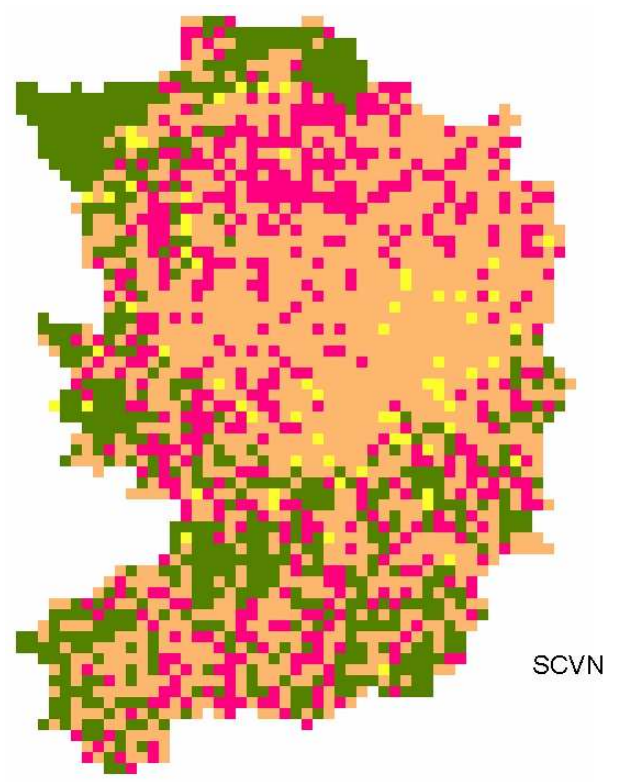
$\square$ Unsuitable
$\square$ Suitable crops
$\square$ Suitable agri-env.
$\square$ Suitable both


Table 3 : significant driving factors for the Beauce case study; grey cases show non-significant coefficients

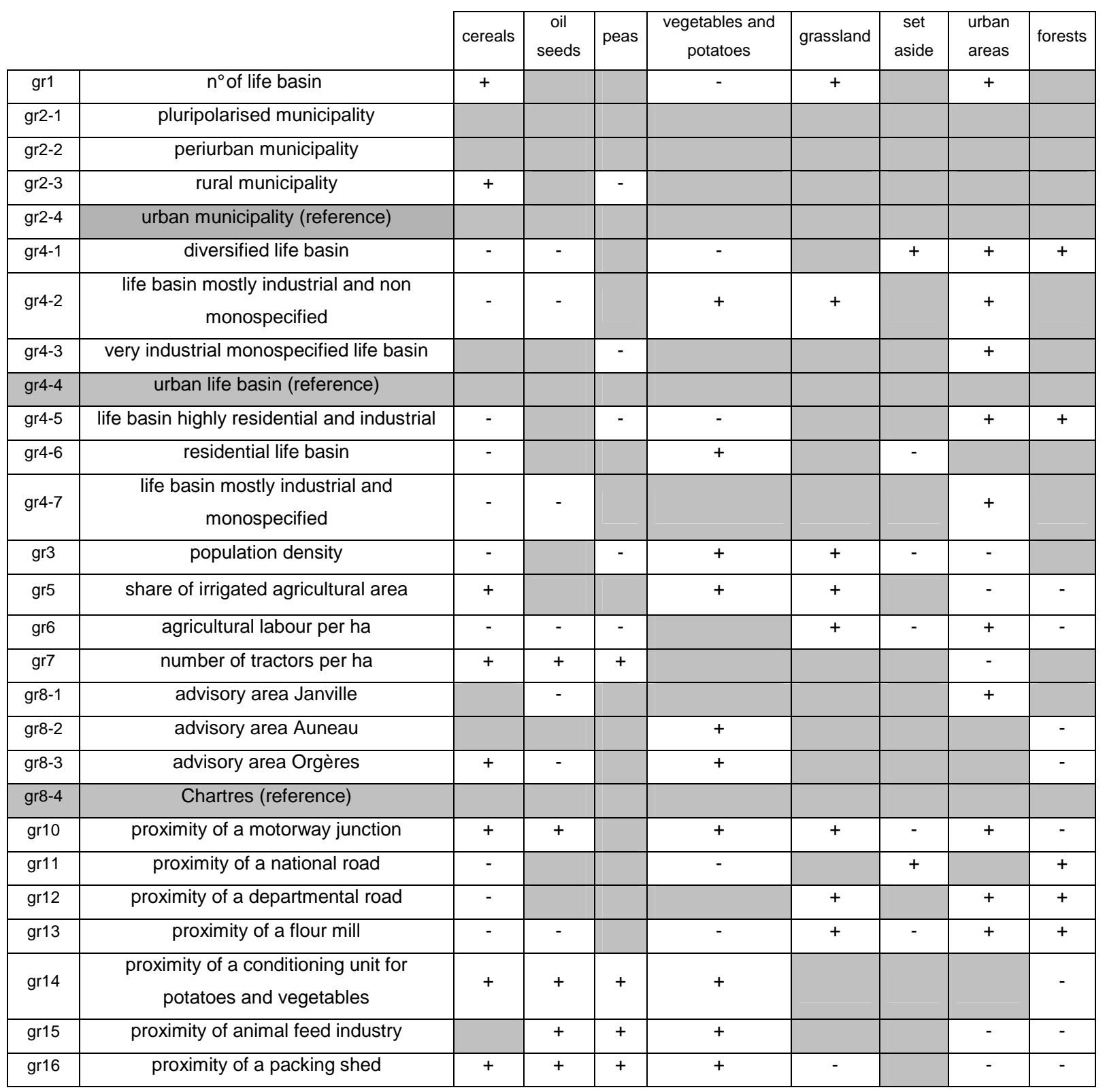

Table 4: number of unsuitable and suitable windows for partridges and connectivity (number of adjacent windows of the same type) between suitable windows for different scenarios

\begin{tabular}{|c|c|c|c|c|c|c|c|c|c|c|}
\hline \multirow[b]{2}{*}{ scenario } & \multicolumn{4}{|c|}{ number of windows } & \multicolumn{6}{|c|}{ connectivity } \\
\hline & unsuitable & $\begin{array}{c}\text { suitable } \\
\text { crop diversity }\end{array}$ & $\begin{array}{l}\text { suitable } \\
\text { agri-env }\end{array}$ & $\begin{array}{c}\text { suitable } \\
\text { both }\end{array}$ & $\begin{array}{l}\text { suitable } \\
\text { crops }\end{array}$ & $\begin{array}{c}\text { suitable } \\
\text { crop/agri-env }\end{array}$ & $\begin{array}{l}\text { suitable } \\
\text { crop/both }\end{array}$ & $\begin{array}{l}\text { suitable } \\
\text { agri-env }\end{array}$ & $\begin{array}{c}\text { suitable } \\
\text { agri-env/both }\end{array}$ & $\begin{array}{c}\text { suitable } \\
\text { both }\end{array}$ \\
\hline initial situation & 1830 & 609 & 0 & 0 & 355 & 0 & 0 & 0 & 0 & 0 \\
\hline $\mathrm{SC} 0$ & 1781 & 650 & 6 & 2 & 398 & 6 & 2 & 1 & 1 & 0 \\
\hline $\operatorname{scN}$ & 670 & 539 & 26 & 1204 & 334 & 17 & 1107 & 0 & 69 & 1327 \\
\hline $\mathrm{scVO}$ & 670 & 539 & 26 & 1204 & 334 & 17 & 1107 & 0 & 69 & 1327 \\
\hline $\mathrm{scVN}$ & 613 & 514 & 66 & 1246 & 290 & 33 & 1049 & 10 & 152 & 1452 \\
\hline
\end{tabular}

